Article

\title{
Environmental Warning System Based on the DPSIR Model: A Practical and Concise Method for Environmental Assessment
}

\author{
Wenqi Wang ${ }^{1}$, Yuhong Sun ${ }^{2, *}$ and Jing $\mathrm{Wu}^{1, *}$ \\ 1 College of Environmental Science and Engineering, Nankai University, Tianjin 300350, China; \\ 2120170637@mail.nankai.edu.cn \\ 2 Yunnan Provincial Appraisal Center for Environmental Engineering, Kunming 650032, China \\ * Correspondence: syhong202@163.com (Y.S.); wujing@nankai.edu.cn (J.W.)
}

Received: 7 May 2018; Accepted: 17 May 2018; Published: 25 May 2018

\begin{abstract}
Though we are in urgent need of environmental warnings to slow environmental deterioration, currently, there is no internationally concise method for environmental warnings. In addition, the existing approaches do not combine the three aspects of ecology, resources, and environment. At the same time, the three elements of the environment (air, water, and soil) are separated in most environmental warning systems. Thus, the method this paper gives is an innovative attempt and aims to make environmental assessment more practical. This paper establishes the index system of an environmental early warning based on the Driving-Pressure-State-Influence-Response (DPSIR) model. The Analytic Hierarchy Process (AHP) method was used to determine the weights. Next, single and integrated index methods further assess the environmental warning state, in which the weighted summation method is used to summarize the data and results. The case of Tianjin is used to confirm the applicability of this method. In conclusion, the method in this paper is more well-behaved and, therefore, more suitable to assist cities in their environmental assessment.
\end{abstract}

Keywords: DPSIR; environmental warning; environmental impact assessment; index system

\section{Introduction}

With the development of society, although the economic development met the growing material needs of people, it also brought a great negative externality to the environment, such as the rise of the particulate matter that has an aerodynamic diameter of 2.5 microns or smaller $\left(\mathrm{PM}_{2.5}\right)$, the eruption of cyanobacteria, the emergence of black and smelly rivers, and the heavy metal pollution of the soil. These environmental deterioration problems have attracted widespread attention and urgently call for more effective environmental governance policies to reduce the environmental pollution. Only by doing this can we achieve a win-win situation for economic development and environmental protection. Furthermore, environmental warning, as an effective policy, can speed up the construction of ecological civilization and ecological protection.

Early warning, that is, the provision of timely and effective information through identified institutions, allows individuals exposed to a hazard to take action to avoid or reduce their risk and prepare an effective response [1]. Similarly, timely environmental warnings can predict the degradation and deterioration of environmental quality caused by industrial development activities [2]. They have a pioneering, predictive, and advanced function, as well as a vigilance effect on the evolutionary trend, direction, speed, and consequences [3]. Therefore, carrying out environmental early warning is an important measure to implement decision-making arrangements and promote the formation of a green development mode. It is also a key point for promoting environmental impact assessment (EIA) and strategic environmental assessment (SEA) and improving land space governance system. 
In previous studies, environmental warnings were divided into environmental carrying capacity warning, environmental risk warning, and environmental ecology warning.

Environmental carrying capacity warning is still in its infancy. The study of environmental carrying capacity evolved from the study of the land carrying capacity in ecology and the concept of environmental capacity [4]. In the past years, Scholars [5-9] introduced early warning systems for marine, livestock and poultry breeding, and river carrying capacity. At this stage, many carrying capacity warning methods are beginning to emerge, such as the Long-Term Ecosystem Research and Monitoring Method (LTERM) proposed by Parr. In the last five years, early warning systems for marine carrying capacity have developed tremendously, such as for Xiamen Bay [10] and Qingdao [11]. Moreover, the water carrying capacity warning has entered a period of rapid growth [12-17], including in Yogyakarta Urban Area (YUA), the Liao River Basin, the Haihe, Yangtze River, and Kunming. It is worth mentioning that more and more scholars turn from single carrying capacity warning to the comprehensive carrying capacity warning, such as case studies of Henan Province [18] and the Beijing-Tianjin-Hebei region [19]. At the same time, many methods have been adopted to calculate carrying capacity in early warning systems such as index evaluation, state space, the ecological footprint, the system dynamics model, single factor analysis, fuzzy comprehensive evaluation, and studio analysis [20].

With the increasing importance of accidental pollution incidents control, environmental risk warning has gained widespread attention in developed countries since the 1970s. In 1989, the United Nations Environment Program proposed the Awareness and Preparedness for Emergencies at Local Level (APELL) Program [21]. As early as the last century, the Danube River Basin Water Pollution Warning System was developed jointly by Germany and Austria, and the German water pollution early warning system was developed in the Rhine River Basin [22]. Today, through thirty years of development, the environmental risk warning system has already made great progress in a range of applications, which usually focused on the water quality emergency risk and catastrophes. Accordingly, with the development of the water quality emergency risk, a mobile environment decision support system (MEWSUB) [23-25] has been built and, for catastrophe warning, the United Nations' International Strategy for Disaster Reduction (ISDR) suggested that early warning systems possessed the following four mechanisms [26,27]: risk knowledge, monitoring and warning service, dissemination and communication, and response capability. In addition, since 2013, the Ministry of Environmental Protection issued a notice that, to improve air pollution prevention and mitigate the impact of pollution, all localities should strengthen the air early warning under the heavily polluted weather. Therefore, Chinese scholars [28-30] used forecasting models and fuzzy evaluation to make early warning systems in Taiyuan, Harbin, Chongqing, Chengdu, and Hangzhou.

Since the development of environmental ecology warning, relevant theories have been constantly improved and technical methods have been updated, and there were both single warnings and comprehensive warnings in ecological warning. In terms of single warnings, there were flood warning systems, pasture warning systems, and soil warning systems. In terms of comprehensive warning, the United Nations Development Program established the Division of Early Warning and Assessment (DEWA) system. In addition to the establishment of national institutions, scholars also concentrated on comprehensive warnings on soil, cultivated land, and agriculture [31-34]. In China, the research on environmental ecological warning has been given more attention by academics. At the provincial and municipal scales, scholars used gray system theory and BP artificial neural networks to study the influence of factors in Inner Mongolia Autonomous Region, Suzhou, Kaifeng, Huangshan, Zhengzhou, and Shanghai to propose measures for sustainable development [35,36]. At the environmental ecology warning river basins scale, scholars used available environmental ecology warning data to study the typical river basin in the Yellow River Delta, Dongting Lake, Chaohu Lake, Tumen River, Tuojiang River, Wujiang River, and Heihe River [37-39].

In July 2016, the Ministry of Environmental Protection published the "Implementation Plan for the Reform of Environmental Impact Assessment in the 13th Five-Year Plan period" [40], calling for 
the establishment of environment early warning systems based on big data, formulating early warning indicator systems, models, and technical methods. To meet new requirements, we have to reconstruct the index system of environmental warnings.

Combining the three major environmental factors of water, atmosphere, and soil, and considering the related requirements in China's strategic environmental assessment (SEA), this study innovatively divided environmental early warning into three aspects. The first one is environmental ecology warning, which can reflect the current situation and trend of ecology overall. The second one is the environmental quality warning, which represents not only a better or worse environment, but also the bottom line of the environmental elements. Environmental quality warning in this study is similar to the environmental carrying capacity warning, but it is more accurate than the carrying capacity warning in reflecting the environmental deterioration trend. Briefly, environmental quality warning, in this study, is that which starts an early warning before it reaches its bearing capacity. The last one is environmental resources warning. In this research, we mainly study water resources warnings, which can delimit the upper limit of water resources utilization.

This paper is divided into six sections. Section 1 is the research background and status quo at home and abroad. Section 2 introduces the research methods, including the model selection, construction of index system, weight determination, index grading and two index evaluation methods. In Section 3 , a case study of Tianjin is used to verify the rationality of the methods. The results show that the ecological environment in Tianjin is facing more pressure and the air, water, soil, and ecosystems are in poor condition. To promote the sustainable and coordinated development of the environment and economy in Tianjin, ecological corridors and biodiversity conservation networks should be established. Finally, some significant discussion points and conclusions are listed.

\section{Methods}

\subsection{Model Selection}

At present, most of the studies on index systems adopt the Driving-Pressure-State-InfluenceResponse (DPSIR) model. In 1979, Canada pioneered the State-Response (S-R) model. Later, the S-R model evolved into the Pressure-State-Response (PSR) model. Afterwards, the PSR model evolved into DPSIR model that included human activities, stress, environmental state, impacts on ecosystems, human health, and political responses [41,42].

The practical application over the years has shown that the DPSIR model has the advantages of comprehensiveness, operability, systematization, and integrity. First, the DPSIR model covers important elements of economy, society, resources, and environment, which can clearly and simply reflect the relationship between the environment and other factors, thus it can provide a scientific theoretical basis for policymakers. Secondly, it not only indicates the influence of society, economic development, and human behavior on the consumption of resources and ecological environment, but also shows the feedback of human behavior and its final lead to the state of resources and environment, which makes the whole system a cycle. Thirdly, it provides a basic framework for the construction of the environmental index system and is suitable for early warnings and the assessment of the environment. Lastly, its evaluation process is relatively easy to operate and use, which brings convenience to scientific researchers.

Therefore, this study used the DPSIR model as a research method.

\subsection{Construction of the Index System}

Based on the DPSIR model, reference was made to the "National Environmental Protection Plan for the Thirteenth Five-year" [43], "Opinions on Implementing a Strict Water Resources Management System" [44], "Opinions on the Delineation and Strict Adherence to the Control Line of Ecological Protection" [45], and "the Technical Guide for the Delimitation of the Control Line of Ecological Protection" [46]. The index system of environmental warnings was analyzed layer by layer. Taking into 
account the comprehensiveness, dynamic continuity, operability, and the qualitative and quantitative combination of indicators, the index system was established.

The driving force (D) is used to express the human social and economic activities. In general, population growth and demand development are the most fundamental driving forces. Therefore, in this study, the driving force indicators mainly reflected the population and economic level. Considering that Population density and GDP cannot accurately measure population and economic level, we used the correlation coefficient to modify indicators. Thus, Driving force (D) in this research includes the population concentration degree and the economic development level.

Pressure $(P)$ exerts directly to the environment under the action of Driving force (D). Similar to the Driving force (D), Pressure (P) is the external force acting on the development and change of the environment. However, the Driving force (D) exerts the effect on the environmental implicitly while Pressure $(\mathrm{P})$ does so explicitly. Additionally, Pressure $(\mathrm{P})$ usually reflects the environmental impact of human activities, waste discharge, and resource consumption. Therefore, in this index system, the pressure indicators include the Reduction of the construction land area per RMB 10,000 of GDP, industrial exhaust emissions per capita, sewage discharge per unit area, the fertilizer utilization rate, the water consumption per 10,000 Yuan GDP, and the water consumption per 10,000 Yuan of industrial added value.

State (S) directly reflects the state of environment under the current pressure, which is usually indicated by the indicators related to the efficiency and compliance rate. Impact (I) is caused by human activities that brings pressure on the environment and causes changes in the environment and human health. Therefore, the index system includes the ecological redline rate, cultivated land safety index, eco-environmental quality index, percentage of days per year with good air quality in cities, severe air pollution rate, centralized drinking water sources quality compliance rate, water functional area compliance rate, cultivated land soil quality compliance rate, contaminated land safe utilization rate, water resources per capita, water supply in ecological environment, and the groundwater over-exploitation rate.

Response (R) is the measures taken by individuals, social groups, or governments to prevent and control the ecological environment damage and pollution or improve the environmental quality and adapt to new environmental changes, which include the forest cover rate, soil erosion control rate, environmental pollution loss rate, effective utilization coefficient of farmland irrigation water, sewage centralized treatment rate, recycled water utilization rate (six quantitative indicators), the environmental management system soundness, and the environmental risk system perfection (two qualitative indicators).

The calculation method of each indicator is listed in Appendix A. The overall framework and specific indicators of the environment warning index system are shown in Figure 1 and Table 1.

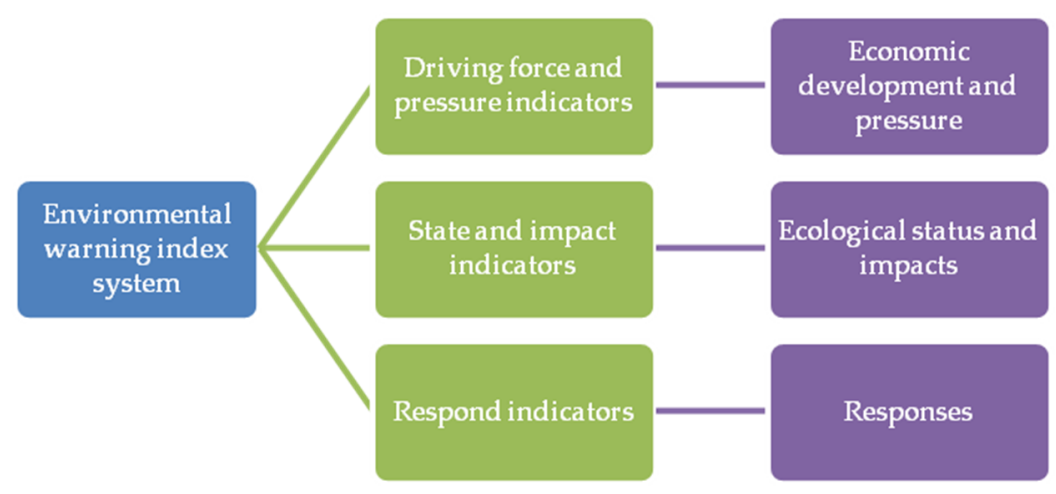

Figure 1. The environmental warning index system framework. 
Table 1. The environmental early warning index system.

\begin{tabular}{|c|c|c|c|c|c|}
\hline \multirow{2}{*}{ DPSIR } & \multirow{2}{*}{$\begin{array}{l}\text { Ecological } \\
\text { Protection }\end{array}$} & \multicolumn{3}{|c|}{ Environmental Quality } & \multirow{2}{*}{ Water Resources } \\
\hline & & Air & Water & Soil & \\
\hline D & & \multicolumn{4}{|c|}{ Population concentration degree, Economic development level } \\
\hline $\mathbf{P}$ & $\begin{array}{l}\text { Reduction of } \\
\text { construction land } \\
\text { area per RMB } \\
10,000 \text { of GDP }\end{array}$ & $\begin{array}{l}\text { Industrial } \\
\text { exhaust } \\
\text { emissions per } \\
\text { capita }\end{array}$ & $\begin{array}{l}\text { Sewage } \\
\text { discharge per } \\
\text { unit area }\end{array}$ & $\begin{array}{l}\text { Fertilizer utilization } \\
\text { rate }\end{array}$ & $\begin{array}{l}\text { Water consumption } \\
\text { per RMB } 10,000 \text { of } \\
\text { GDP, } \\
\text { water consumption } \\
\text { per RMB } 10,000 \text { of } \\
\text { industrial added } \\
\text { value }\end{array}$ \\
\hline$S$ and $I$ & $\begin{array}{l}\text { Ecological redline } \\
\text { rate, } \\
\text { cultivated land } \\
\text { safety index, } \\
\text { eco-environmental } \\
\text { quality index }\end{array}$ & $\begin{array}{l}\text { Percentage of } \\
\text { days per year } \\
\text { with good air } \\
\text { quality in cities, } \\
\text { percentage of } \\
\text { days per year } \\
\text { with severe air } \\
\text { pollution in } \\
\text { cities }\end{array}$ & $\begin{array}{l}\text { Centralized } \\
\text { drinking water } \\
\text { sources quality } \\
\text { compliance } \\
\text { rate, water } \\
\text { functional area } \\
\text { compliance rate }\end{array}$ & $\begin{array}{l}\text { Cultivated land soil } \\
\text { quality compliance } \\
\text { rate, contaminated } \\
\text { land safe utilization } \\
\text { rate }\end{array}$ & $\begin{array}{l}\text { Water resources per } \\
\text { capita, water supply } \\
\text { in ecological } \\
\text { environment, } \\
\text { groundwater } \\
\text { over-exploitation } \\
\text { rate }\end{array}$ \\
\hline $\mathbf{R}$ & $\begin{array}{l}\text { Forest coverage } \\
\text { rate, soil erosion } \\
\text { control rate }\end{array}$ & $\begin{array}{l}\text { Environmental } \mathrm{m} \\
\text { environmental ri } \\
\text { environmental p }\end{array}$ & $\begin{array}{l}\text { anagement systen } \\
\text { k system perfecti } \\
\text { llution loss rate }\end{array}$ & soundness, & $\begin{array}{l}\text { Effective utilization } \\
\text { coefficient of } \\
\text { farmland irrigation } \\
\text { water, sewage } \\
\text { centralized treatment } \\
\text { rate, recycled water } \\
\text { utilization rate }\end{array}$ \\
\hline
\end{tabular}

\subsection{Weight Determination}

There are many ways to determine the weight of indicators, such as the Analytic Hierarchy Process (AHP), Expert consultation, Fuzzy comprehensive evaluation, Principal component analysis, Sequence synthesis, and Coordination evaluation. Analytic Hierarchy Process (AHP) is not only widely used in different fields such as the environment, society, and economy but also developed in theory [47]. It is also applicable to the index system with fewer indicators, which is practical. Therefore, in this research, AHP was used to weight the indicators of the criterion levels.

The specific method is as follows: first, construct the judgment comparison matrix, compare the importance of two given factors, and use the -9 scale system proposed by Saaty to determine the value in the judgment matrix. Secondly, use SUM in Excel to calculate the largest eigenvalue $\left(\lambda_{\max }\right)$ and its corresponding eigenvector, normalize each column of the judgment matrix to obtain the corresponding weight and calculate the arithmetic mean of each column vector as the final weight, that is, the sorted importance of each evaluation index. Finally, we test the matrix consistency.

$$
\text { Consistency Index }(\mathrm{CI})=\left(\lambda_{\max }-\mathrm{n}\right) /(\mathrm{n}-1)
$$

Consistency Rate $(\mathrm{CR})=$ Consistency Index $(\mathrm{CI}) /$ Random Index (RI)

The random consistency index RI is shown in Table 2. After examination, the CR of the matrix set in this research was less than 0.1 , which is considered to be in good agreement.

Table 2. The random consistency index (RI).

\begin{tabular}{ccccccccccc}
\hline Matrix Order & $\mathbf{1}$ & $\mathbf{2}$ & $\mathbf{3}$ & $\mathbf{4}$ & $\mathbf{5}$ & $\mathbf{6}$ & $\mathbf{7}$ & $\mathbf{8}$ & $\mathbf{9}$ & $\mathbf{1 0}$ \\
\hline RI & 0 & 0 & 0.52 & 0.89 & 1.12 & 1.26 & 1.36 & 1.41 & 1.46 & 1.49 \\
\hline
\end{tabular}




\subsection{Index Grading}

Index grading of this study was mainly based on existing environmental standards, relevant national guidelines, management methods, eco-villages, and eco-provincial construction indicators, as well as existing research literature and provincial data. Specifically, the grading sources of specific indicators were as follows:

(1) "Resources-Environment-Economy Compound System Diagnostic Early Warning Method and Application" [48];

(2) "Practice and Exploration on Resources and Environmental Carrying Capacity Monitoring and Early Warning of the Sichuan Province" [49];

(3) "Guiding Opinions on the Implementation of Decreasing Construction Land Area Per Gross Domestic Product in the 13th Five-Year" [50];

(4) "Temporal and Spatial Distribution of Cropland-Population-Grain System and Pressure Index on the Cropland in the Jinghe Watershed" [51];

(5) "Eco-Environment Security Assessment Study for the Binhai New Area, Tianjin, Based on the DPSIR Model" [52];

(6) "Soil Erosion Prevention and Control Standards for Construction Projects" (GB50434-2008) [53];

(7) "Indicators of National Ecological Civilization Demonstration Counties and Cities (Trial Implementation)" [54];

(8) "Action Plan for Zero Growth of Fertilizer Consumption by 2020" [55];

(9) "National Environmental Protection Plan for the Thirteenth Five-Year" [43];

(10) "Action Plan for the Prevention and Control of Soil Pollution" [56];

(11) "Study on Urban Eco-Environmental Water Requirements: Theory and Method" [57];

(12) "Guidelines for the Evaluation of Groundwater Overdraft Area (GB/T 34968-2017)" [58];

(13) "Green is Gold: The Strategy and Actions of China's Ecological Civilization" [59]; and

(14) “Opinions on Implementing Strict Water Resources Management System" [44].

Afterwards, referring to the provinces environmental statement, based on the five grades determined, the index grading of all indicators were ascertained.

The warning weight setting and index grading are shown in Tables 3-7.

Table 3. The environmental ecology warning weight setting and index grading.

\begin{tabular}{|c|c|c|c|c|c|c|c|c|}
\hline $\begin{array}{c}\text { Standard } \\
\text { Layer }\end{array}$ & Index Layer & Attribute & Weight & Red & Orange & Yellow & Green & Blue \\
\hline \multirow{2}{*}{ D } & $\begin{array}{l}\text { Population concentration } \\
\text { degree (people per square } \\
\text { kilometer) }\end{array}$ & Negative & $9.09 \%$ & $>300$ & $200-300$ & $120-200$ & $5-120$ & $<5$ \\
\hline & $\begin{array}{l}\text { Economic development } \\
\text { level (ten-thousand Yuan } \\
\text { per person) }\end{array}$ & Positive & $9.09 \%$ & $<1$ & $1-2$ & $2-4.5$ & $4.5-8$ & $>8$ \\
\hline $\mathbf{P}$ & $\begin{array}{l}\text { Reduction of construction } \\
\text { land area per RMB 10,000 of } \\
\text { GDP (\%) }\end{array}$ & Positive & $4.55 \%$ & $<16$ & $16-18$ & $18-20$ & $20-22$ & $>22$ \\
\hline \multirow{3}{*}{$S$ and $I$} & Ecological redline rate (\%) & Positive & $18.18 \%$ & $<10$ & $10-20$ & $20-30$ & $30-40$ & $>40$ \\
\hline & $\begin{array}{l}\text { Cultivated land safety } \\
\text { index }\end{array}$ & Negative & $4.55 \%$ & $>1.3$ & $1.1-1.3$ & $1-1.1$ & $0.9-1$ & $<0.9$ \\
\hline & $\begin{array}{l}\text { Eco-environmental quality } \\
\text { index }\end{array}$ & Positive & $18.18 \%$ & $<20$ & $20-35$ & $35-55$ & $55-75$ & $>75$ \\
\hline \multirow{2}{*}{$\mathbf{R}$} & Forest coverage rate $(\%)$ & Positive & $18.18 \%$ & $<10$ & $10-20$ & $20-35$ & $35-45$ & $>45$ \\
\hline & Soil erosion control rate (\%) & Positive & $18.18 \%$ & $<65$ & $65-75$ & $75-85$ & $85-95$ & $>95$ \\
\hline
\end{tabular}


Table 4. The environmental air quality warning weight setting and index grading.

\begin{tabular}{|c|c|c|c|c|c|c|c|c|}
\hline $\begin{array}{l}\text { Standard } \\
\text { Layer }\end{array}$ & Index Layer & Attribute & Weight & Red & Orange & Yellow & Green & Blue \\
\hline \multirow{2}{*}{ D } & $\begin{array}{l}\text { Population concentration } \\
\text { degree (people per square } \\
\text { kilometer) }\end{array}$ & Negative & $7.69 \%$ & $>300$ & $200-300$ & $120-200$ & $5-120$ & $<5$ \\
\hline & $\begin{array}{l}\text { Economic development } \\
\text { level (ten-thousand Yuan } \\
\text { per person) }\end{array}$ & Positive & $7.69 \%$ & $<1$ & $1-2$ & $2-4.5$ & $4.5-8$ & $>8$ \\
\hline $\mathbf{P}$ & $\begin{array}{l}\text { Industrial exhaust } \\
\text { emissions per capita } \\
\text { (ten-thousand cubic meters } \\
\text { per person) }\end{array}$ & Negative & $15.38 \%$ & $>2$ & $1.5-2$ & $1-1.5$ & $0.5-1$ & $<0.5$ \\
\hline \multirow{2}{*}{$S$ and $I$} & $\begin{array}{l}\text { Percentage of days per year } \\
\text { with good air quality in } \\
\text { cities }(\%)\end{array}$ & Positive & $15.38 \%$ & $<50$ & $50-60$ & $60-70$ & $70-80$ & $>80$ \\
\hline & $\begin{array}{l}\text { Percentage of days per year } \\
\text { with severe air pollution in } \\
\text { cities }(\%)\end{array}$ & Negative & $15.38 \%$ & $>15$ & $10-15$ & $5-10$ & $2-5$ & $<2$ \\
\hline \multirow{3}{*}{$\mathbf{R}$} & $\begin{array}{l}\text { Environmental } \\
\text { management } \\
\text { system soundness }\end{array}$ & Positive & $15.38 \%$ & Unsound & $\begin{array}{l}\text { Less } \\
\text { sound }\end{array}$ & $\begin{array}{l}\text { General } \\
\text { sound }\end{array}$ & $\begin{array}{l}\text { More } \\
\text { sound }\end{array}$ & Sound \\
\hline & $\begin{array}{l}\text { Environmental risk system } \\
\text { perfection }\end{array}$ & Positive & $7.69 \%$ & Imperfect & $\begin{array}{c}\text { Less } \\
\text { perfect }\end{array}$ & $\begin{array}{l}\text { General } \\
\text { perfect }\end{array}$ & $\begin{array}{l}\text { More } \\
\text { perfect }\end{array}$ & Perfect \\
\hline & $\begin{array}{l}\text { Environmental pollution } \\
\text { loss rate }(\%)\end{array}$ & Positive & $15.38 \%$ & $>5$ & $4-5$ & $3-4$ & $2-3$ & $<2$ \\
\hline
\end{tabular}

Table 5. The environmental water quality warning weight setting and index grading.

\begin{tabular}{|c|c|c|c|c|c|c|c|c|}
\hline $\begin{array}{l}\text { Standard } \\
\text { Layer }\end{array}$ & Index Layer & Attribute & Weight & Red & Orange & Yellow & Green & Blue \\
\hline \multirow{2}{*}{$\mathbf{D}$} & $\begin{array}{l}\text { Population concentration } \\
\text { degree (people per square } \\
\text { kilometer) }\end{array}$ & Negative & $7.69 \%$ & $>300$ & $200-300$ & $120-200$ & $5-120$ & $<5$ \\
\hline & $\begin{array}{l}\text { Economic development } \\
\text { level (ten-thousand Yuan } \\
\text { per person) }\end{array}$ & Positive & $7.69 \%$ & $<1$ & $1-2$ & $2-4.5$ & $4.5-8$ & $>8$ \\
\hline $\mathbf{P}$ & $\begin{array}{l}\text { Sewage discharge per unit } \\
\text { area (tons per square } \\
\text { kilometer) }\end{array}$ & Negative & $15.38 \%$ & $>10,000$ & $\begin{array}{c}5000- \\
10,000\end{array}$ & $\begin{array}{l}1000- \\
5000\end{array}$ & 100-1000 & $<100$ \\
\hline \multirow[t]{2}{*}{$S$ and $I$} & $\begin{array}{l}\text { Centralized drinking water } \\
\text { sources quality compliance } \\
\text { rate }(\%)\end{array}$ & Positive & $15.38 \%$ & $<85$ & $85-90$ & $90-95$ & 95-100 & 100 \\
\hline & $\begin{array}{l}\text { Water functional area } \\
\text { compliance rate }(\%)\end{array}$ & Positive & $15.38 \%$ & $<65$ & $65-80$ & $80-90$ & 90-100 & 100 \\
\hline \multirow{3}{*}{$\mathbf{R}$} & $\begin{array}{l}\text { Environmental } \\
\text { management system } \\
\text { soundness }\end{array}$ & Positive & $15.38 \%$ & Unsound & $\begin{array}{l}\text { Less } \\
\text { sound }\end{array}$ & $\begin{array}{l}\text { General } \\
\text { sound }\end{array}$ & $\begin{array}{l}\text { More } \\
\text { sound }\end{array}$ & Sound \\
\hline & $\begin{array}{l}\text { Environmental risk system } \\
\text { perfection }\end{array}$ & Positive & $7.69 \%$ & Imperfect & $\begin{array}{c}\text { Less } \\
\text { perfect }\end{array}$ & $\begin{array}{l}\text { General } \\
\text { perfect }\end{array}$ & $\begin{array}{l}\text { More } \\
\text { perfect }\end{array}$ & Perfect \\
\hline & $\begin{array}{l}\text { Environmental pollution } \\
\text { loss rate }(\%)\end{array}$ & Negative & $15.38 \%$ & $>5$ & $4-5$ & $3-4$ & $2-3$ & $<2$ \\
\hline
\end{tabular}


Table 6. The environmental soil quality warning weight setting and index grading.

\begin{tabular}{|c|c|c|c|c|c|c|c|c|}
\hline $\begin{array}{l}\text { Standard } \\
\text { Layer }\end{array}$ & Index Layer & Attribute & Weight & Red & Orange & Yellow & Green & Blue \\
\hline \multirow[t]{2}{*}{ D } & $\begin{array}{l}\text { Population } \\
\text { Concentration degree } \\
\text { (people per } \\
\text { square kilometer) }\end{array}$ & Negative & $7.69 \%$ & $>300$ & $200-300$ & $120-200$ & $5-120$ & $<5$ \\
\hline & $\begin{array}{l}\text { Economic development level } \\
\text { (ten-thousand Yuan per person) }\end{array}$ & Positive & $7.69 \%$ & $<1$ & $1-2$ & $2-4.5$ & $4.5-8$ & $>8$ \\
\hline $\mathbf{P}$ & Fertilizer utilization rate (\%) & Positive & $15.38 \%$ & $<25$ & $25-30$ & $30-35$ & $35-40$ & $>40$ \\
\hline \multirow{2}{*}{$S$ and $I$} & $\begin{array}{l}\text { Cultivated land soil quality } \\
\text { compliance rate }(\%)\end{array}$ & Positive & $15.38 \%$ & $<80$ & $80-85$ & $85-90$ & $90-95$ & $>95$ \\
\hline & $\begin{array}{l}\text { Contaminated land safe } \\
\text { utilization rate }(\%)\end{array}$ & Positive & $15.38 \%$ & $<80$ & $80-85$ & $85-90$ & $90-95$ & $>95$ \\
\hline \multirow{3}{*}{$\mathbf{R}$} & $\begin{array}{l}\text { Environmental management } \\
\text { system soundness }\end{array}$ & Positive & $15.38 \%$ & Unsound & $\begin{array}{l}\text { Less } \\
\text { sound }\end{array}$ & $\begin{array}{l}\text { General } \\
\text { sound }\end{array}$ & $\begin{array}{l}\text { More } \\
\text { sound }\end{array}$ & Sound \\
\hline & $\begin{array}{l}\text { Environmental risk } \\
\text { system perfection }\end{array}$ & Positive & $7.69 \%$ & Imperfect & $\begin{array}{l}\text { Less } \\
\text { perfect }\end{array}$ & $\begin{array}{l}\text { General } \\
\text { perfect }\end{array}$ & $\begin{array}{l}\text { More } \\
\text { perfect }\end{array}$ & Perfect \\
\hline & $\begin{array}{l}\text { Environmental pollution } \\
\text { loss rate }(\%)\end{array}$ & Negative & $15.38 \%$ & $>5$ & $4-5$ & $3-4$ & $2-3$ & $<2$ \\
\hline
\end{tabular}

Table 7. The environmental water resources warning weight setting and index grading.

\begin{tabular}{|c|c|c|c|c|c|c|c|c|}
\hline $\begin{array}{l}\text { Standard } \\
\text { Layer }\end{array}$ & Index Layer & Attribute & Weight & Red & Orange & Yellow & Green & Blue \\
\hline \multirow{2}{*}{$\mathbf{D}$} & $\begin{array}{l}\text { Population concentration } \\
\text { degree (people per square } \\
\text { kilometer) }\end{array}$ & Negative & $5.88 \%$ & $>300$ & $200-300$ & $120-200$ & $5-120$ & $<5$ \\
\hline & $\begin{array}{l}\text { Economic development } \\
\text { level (yen-thousand Yuan } \\
\text { per person) }\end{array}$ & Positive & $5.88 \%$ & $<1$ & $1-2$ & $2-4.5$ & $4.5-8$ & $>8$ \\
\hline \multirow[b]{2}{*}{$\mathbf{P}$} & $\begin{array}{l}\text { Water consumption per } \\
\text { RMB 10,000 of GDP (tons } \\
\text { per ten thousand Yuan) }\end{array}$ & Negative & $11.76 \%$ & $>200$ & $100-200$ & 50-100 & $30-50$ & $<30$ \\
\hline & $\begin{array}{l}\text { Water consumption per } \\
\text { RMB } 10,000 \text { of industrial } \\
\text { added value (cubic meters } \\
\text { per ten thousand Yuan) }\end{array}$ & Negative & $11.76 \%$ & $>80$ & $60-80$ & $40-60$ & $20-40$ & $<20$ \\
\hline \multirow{3}{*}{$S$ and $I$} & $\begin{array}{l}\text { Water resources per capita } \\
\text { (cubic meters per person) }\end{array}$ & Positive & $11.76 \%$ & $<500$ & $\begin{array}{l}500- \\
2000\end{array}$ & $\begin{array}{l}2000- \\
5000\end{array}$ & $\begin{array}{l}5000- \\
10,000\end{array}$ & $>10,000$ \\
\hline & $\begin{array}{l}\text { Water supply in Ecological } \\
\text { environment (billion cubic } \\
\text { meters) }\end{array}$ & Positive & $11.76 \%$ & $<10$ & $10-20$ & $20-30$ & $30-40$ & $>40$ \\
\hline & $\begin{array}{l}\text { Groundwater } \\
\text { over-exploitation rate (\%) }\end{array}$ & Negative & $11.76 \%$ & $>30$ & $20-30$ & $10-20$ & $0-10$ & 0 \\
\hline \multirow{3}{*}{$\mathbf{R}$} & $\begin{array}{l}\text { Effective utilization } \\
\text { coefficient of farmland } \\
\text { irrigation water }\end{array}$ & Positive & $5.88 \%$ & $<0.3$ & $0.3-0.4$ & $0.4-0.5$ & $0.5-0.6$ & $>0.6$ \\
\hline & $\begin{array}{l}\text { Sewage centralized } \\
\text { treatment rate }(\%)\end{array}$ & Positive & $11.76 \%$ & $<65$ & $65-75$ & $75-85$ & $85-95$ & $>95$ \\
\hline & $\begin{array}{l}\text { Recycled water utilization } \\
\text { rate }(\%)\end{array}$ & Positive & $11.76 \%$ & $<15$ & $15-20$ & $20-25$ & $25-30$ & $>30$ \\
\hline
\end{tabular}




\subsection{Single Index Evaluation}

Because different dimensions of early warning indicators, if not unified, directly affect the specific calculation results, it is necessary to eliminate the dimensions of the original data and convert them into comparable data sequences. The normalized data remove the data limitation and convert them into dimensionless numbers that are allowed for comparison and weighting across different units or orders of magnitude.

In this research, we used standard deviation to standardize the dimensions and the deviation standardization, also called 0-1 standardization, is a linear transformation of the raw data. The transfer functions are as follows [52]:

$$
\begin{aligned}
& Y=\frac{X-\min (X)}{\max (X)-\min (X)} \\
& Y=\frac{\max (X)-X}{\max (X)-\min (X)}
\end{aligned}
$$

where $\max (X)$ is the maximum value of the grading standard and $\min (X)$ is the minimum grading standard. For a positive index, Formula (3) was used for calculation. For the negative index, Formula (4) was used for calculation.

Then, the research adopted a modified deviation standardization to further the standardization. The specific operations are as follows: after standardization of dispersion, the value of $\mathrm{X}$ is enlarged 10 times. If the positive index is more than the maximum limit, then it is 10; if it is less than the minimum limit, then it is 0 . If the negative index is more than the maximum limit, then it is 0 ; if it is less than the minimum limit, then it is 10 .

Finally, the radar map is used to characterize the environment warning to show changes of the indicators and their good or bad trends.

\subsection{Integrated Index Evaluation}

The method of data standardization in the integrated index method is roughly the same as that of the single index method. It adopts standardization of dispersion (0-1 standardization).

Then, the research adopts modified deviation standardization for further standardization. The specific operations are as follows: after standardization of dispersion, the value of $X$ is enlarged 100 times. If the positive index is more than the maximum limit, then it is 100; if it is less than the minimum limit, then it is 0 . If the negative index is more than the maximum limit, then it is 0 ; if it is less than the minimum limit, then it is 100 .

Finally, the weighted summation method was used to summarize the data and results. According to the relative importance of each indicator, we gave a weight coefficient, so that the importance of different evaluation indicators becomes roughly the same and then we accumulated their evaluation results to obtain a total score. The formula is as follows:

$$
\mathrm{B}=\sum\left(\mathrm{X}_{\mathrm{i}} \times \mathrm{W}_{\mathrm{i}}\right)
$$

where $B$ is the integrated index obtained, $X_{i}$ is the normalized revised value of the ith index data, and $W_{i}$ is the weight of the ith index [60].

After getting the integrated index, we could get the warning level according to Table 8 .

Table 8. The integrated score early warning form.

\begin{tabular}{cccccc}
\hline Warning & Red & Orange & Yellow & Green & Blue \\
\hline Score & $<20$ & $20-40$ & $40-60$ & $60-80$ & $>80$ \\
\hline
\end{tabular}




\section{Model Application-A Case Study of Tianjin City in 2015}

\subsection{An Introduction to Tianjin City}

Tianjin lies between the latitudes of 38 degrees $34 \mathrm{~min}$ and 40 degrees $15 \mathrm{~min}$ north and between the longitudes of 116 degrees $43 \mathrm{~min}$ and 118 degrees 4 min east. Additionally, it is $189 \mathrm{~km}$ from north to south and $117 \mathrm{~km}$ from east to west. It covers 11,917 square kilometers. Facing the outside of Northeast Asia, it has great influence on north China, and the northeast and northwest provinces. It is located in the northern part of the North China Plain, bordering the Bohai Sea to the east and Yanshan to the north, in the lower reaches of the Haihe River and across both banks of the Haihe River. It is an important functional area for water and soil conservation, which focuses on the people, habitat, ecological security protection, and marine ecological protection. Tianjin's geographical location is shown in Figure 2.

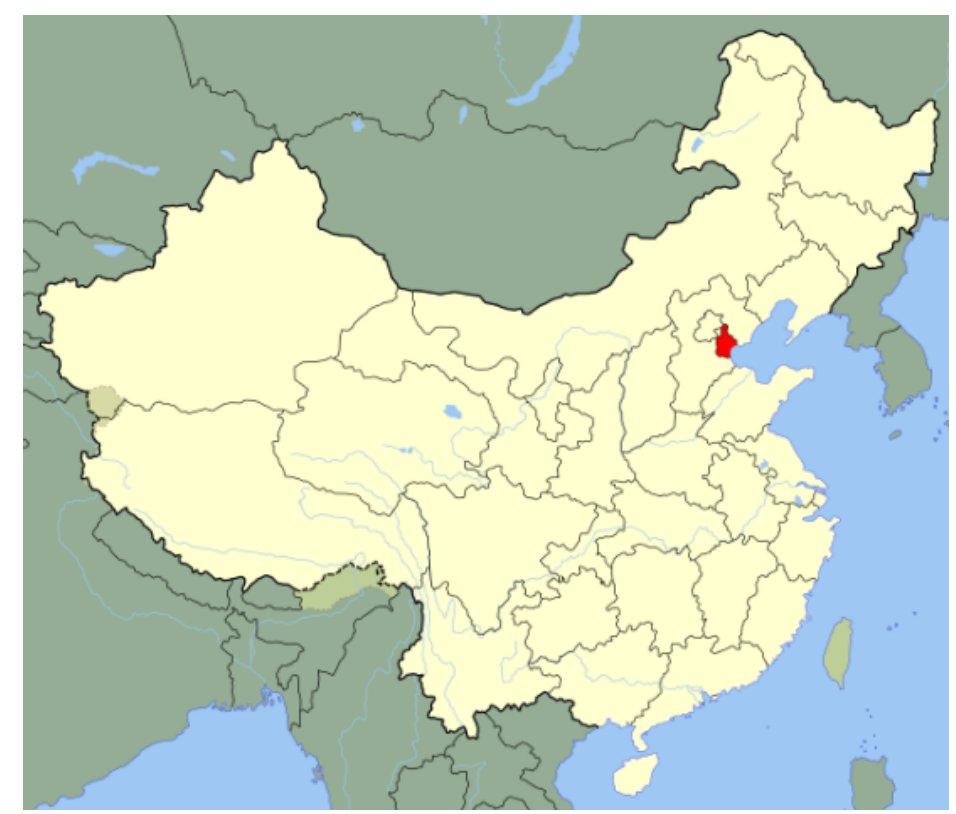

Figure 2. The geographical location of Tianjin.

\subsection{Environment Situation in Tianjin}

Although positive progress has been made in the protection of the atmospheric environment in Tianjin, the coal-dominated energy structure has resulted in a high total amount of air pollutant emissions. The regional air pollution with $\mathrm{PM}_{2.5}$ and $\mathrm{O}_{3}$ as major pollutants has been prominent. Motor vehicle exhaust gas, volatile organic compounds, and other pollution were still serious, the pollution load was high, the energy structure was not reasonable and it was affected by unfavorable weather conditions and field transmission, resulting in the $\mathrm{PM}_{10}, \mathrm{PM}_{2.5}$, and other major pollutants being higher than the standards.

Tianjin was one of the cities that had the least water resources per capita in the country. Water resources were still the key constraint to the economic and social development in Tianjin. At the same time, the state of the water environment pollution in Tianjin was serious. There was a shortage of water for ecological use, lack of water for entry, poor water quality in the upper reaches, prominent contradictions in the cross-border river pollution, sluggish utilization of sludge disposal, low reclaimed water utilization facilities, and little infrastructural construction in rural areas, which resulted in the overall poor quality of the water environment.

Soil types in Tianjin were divided into the mountainous brown soil, cinnamon soil, alluvial soil, swamp soil, and coastal saline soil. Swamp soil was most widely distributed in Tianjin and the soil 
fertility was at a lower level. In general, the quality of the soil environment in Tianjin was in a good state, with only a few pollutants exceeding the standard in some areas. Most of the polluted areas were concentrated in the periphery of the central urban area, which overlapped with the irrigated areas. Cadmium pollution in the irrigated areas was relatively heavy and the organic pollution was dominated by HCHs and DDTs.

All of the above data came from the Tianjin Statistical Yearbook in 2015 [61]; the Tianjin Environmental Statement in 2015 [62]; the Tianjin Water Development Statistical Bulletin in 2015 [63]; the Tianjin Water Resources Bulletin in 2015 [64]; and the National Environmental Protection Plan for the Thirteenth Five-year [43].

\section{Results}

After calculation, the environmental warning radar diagram of Tianjin City in 2015 was drawn by the single index method, as shown in Figures 3-7.

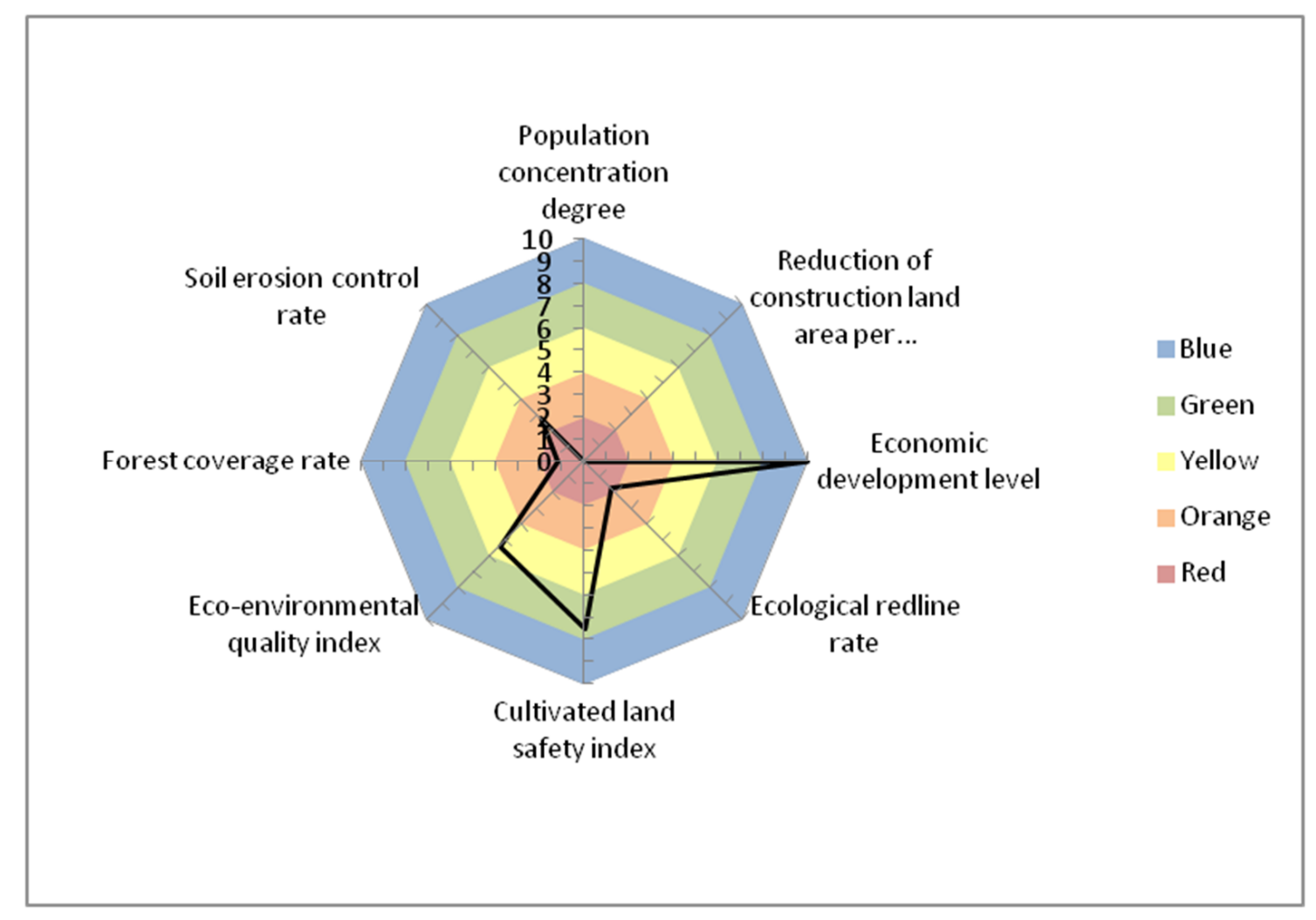

Figure 3. The environmental ecology warning radar map of Tianjin in 2015. 


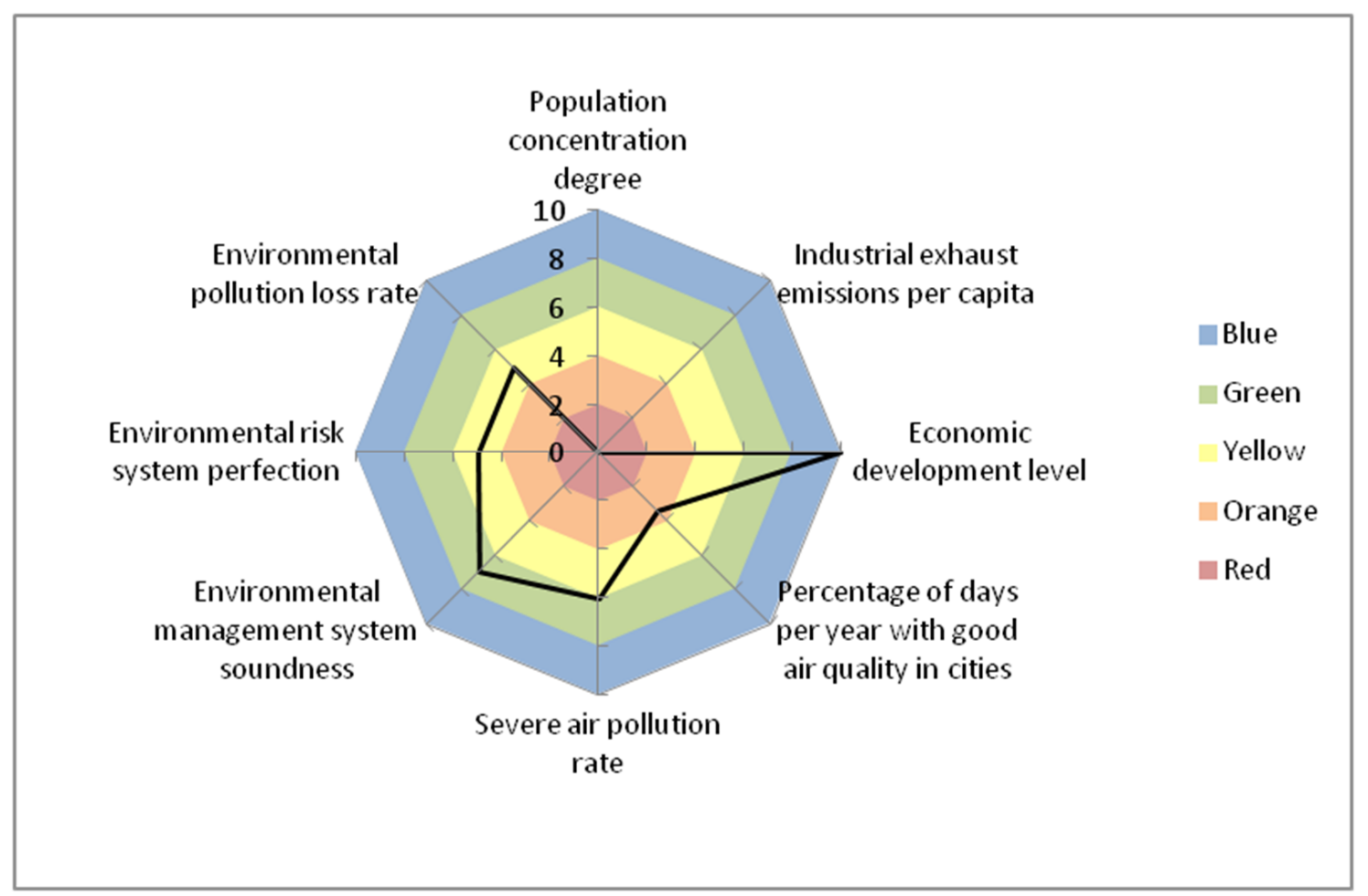

Figure 4. The environmental air quality warning radar map of Tianjin in 2015.

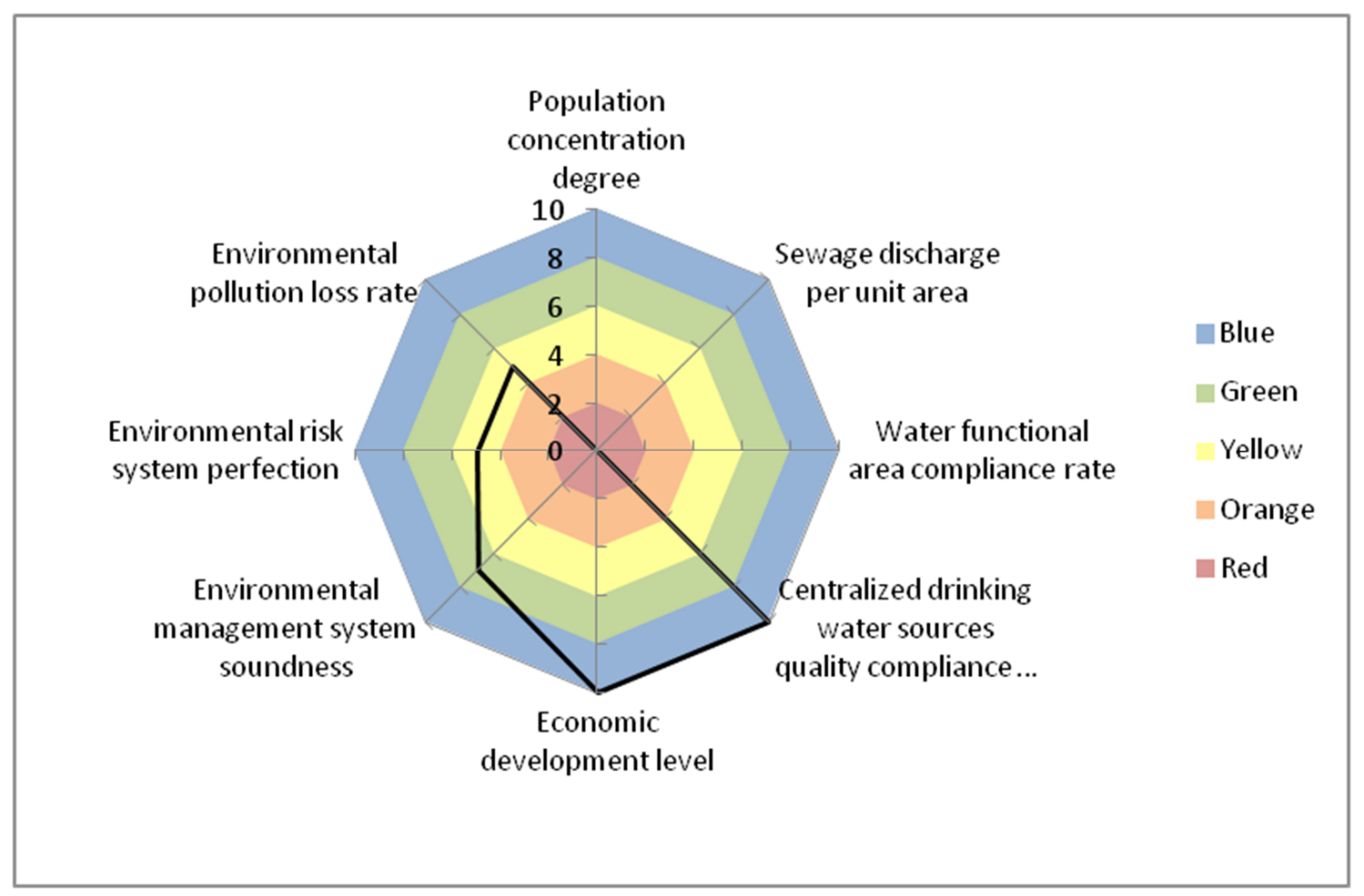

Figure 5. The environmental water quality warning radar map of Tianjin in 2015. 


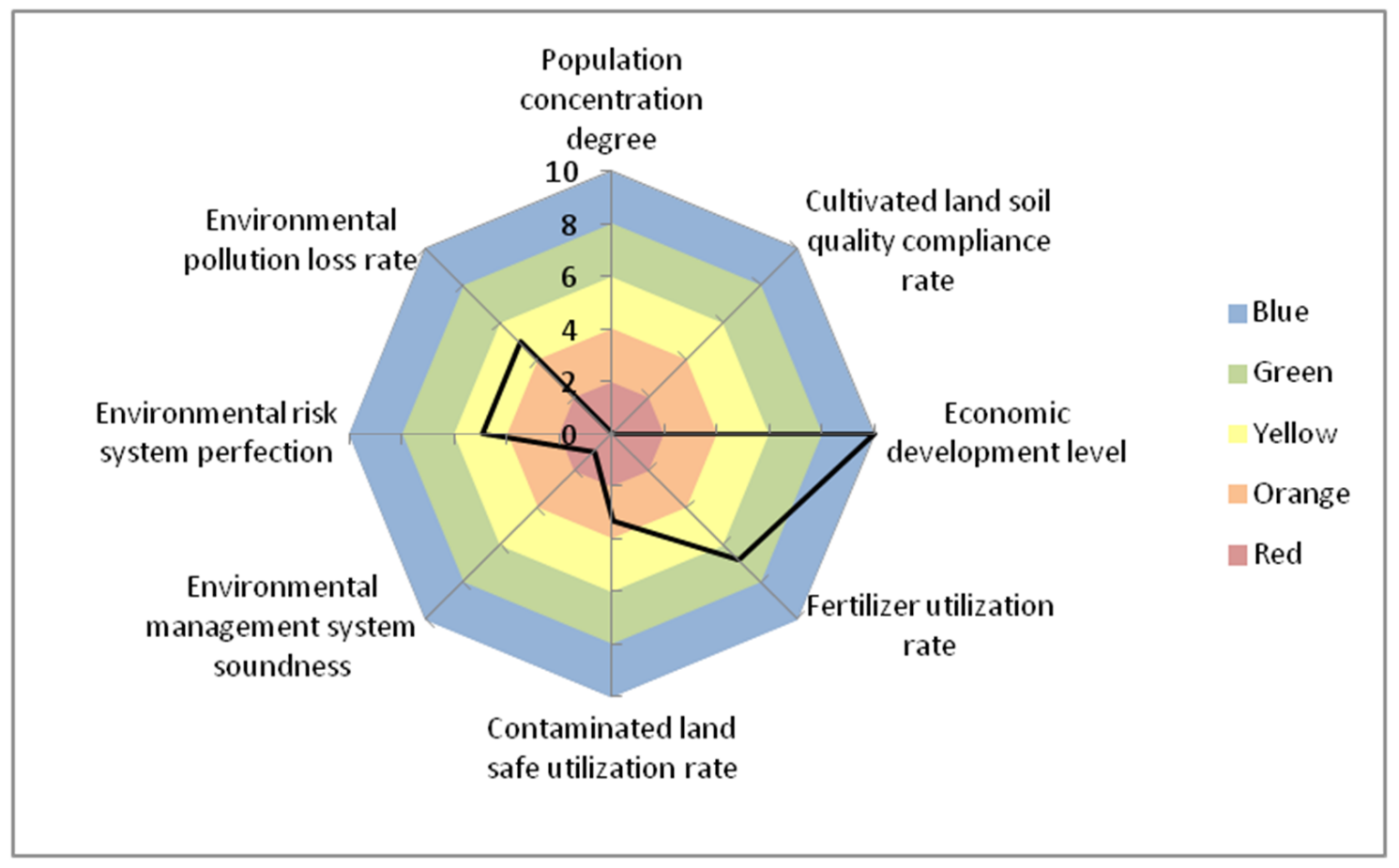

Figure 6. The environmental soil quality warning radar map of Tianjin in 2015.

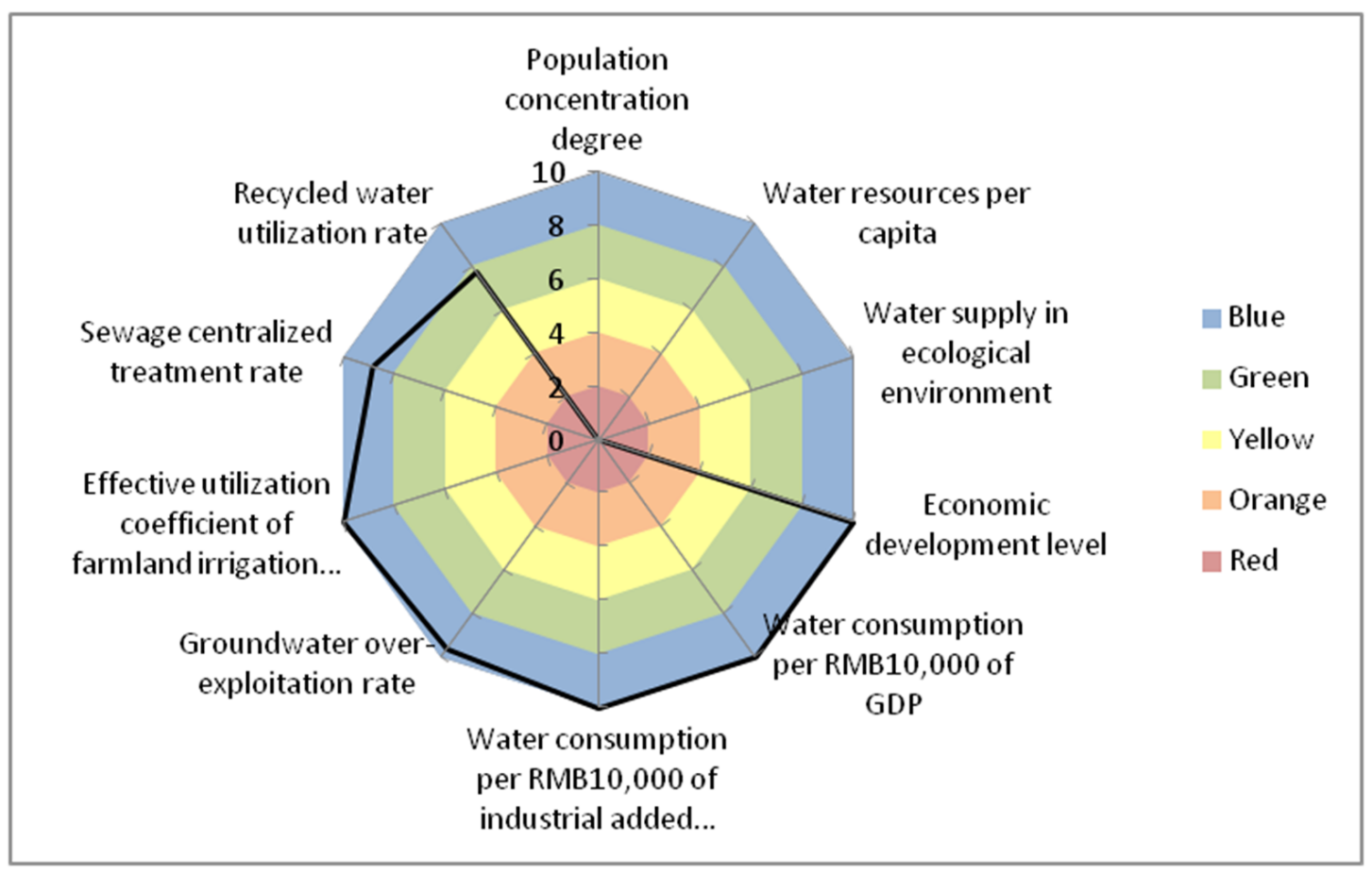

Figure 7. The environmental water resources warning radar map of Tianjin in 2015.

In the figures, it can be found that the population concentration degree in Tianjin was much higher than the national average. Excessive population has already restricted the development of Tianjin's environment. At the same time, Tianjin had a high level of economic development, which could promote the development of environmental technology. On the other hand, it also brought greater pressures on the environment. 
Additionally, the industrial exhaust emissions per capita was up to 54,000 standard cubic meters per person and the sewage discharge per unit area was up to 78,547.47 tons per square kilometer. The reason for the high figures is that Tianjin was a century-old heavy industrial city along the coast. Therefore, the air, water, and soil conditions in Tianjin were poorer, especially since the percentage of days per year with good air quality in cities was only $60.3 \%$ and the water functional area compliance rate was only $15.4 \%$, which were far below the relevant world and Chinese standards. All of these reflected that, in 2015, the compound air pollution in Tianjin was prominent and the industrial air pollutants dominated the air; the water pollution state in Tianjin was severe and the aquatic ecosystem was deteriorated; the accumulated soil pollution and organic pollution caused by sewage irrigation were both serious. Moreover, in terms of the system and measures, the environmental management system soundness and the environmental risk system perfection were less than perfect. In general, with significant differences, the development of the various early warning indicators was not balanced.

As for water resources, the indicators were extremely uneven. The water resources per capita was only 124.84 cubic meters per person and the water supply in the ecological environment was 3.99 billion cubic meters. It could be seen that Tianjin's water resources were extremely scarce, far below the world average. Fortunately, the effective utilization coefficient of the farmland irrigation water, sewage centralized treatment rate, and recycled water utilization rate were high enough, which reflected the high degree of water resource utilization in Tianjin. Therefore, although Tianjin's water resources were extremely scarce, the lives of local residents had not been particularly affected.

According to the weighted summation method, the environmental ecology warning integrated index of Tianjin in 2015 was 32.66/100 and the warning level was orange; the environmental air quality warning integrated index of Tianjin in 2015 was 44.59/100 and the warning level was yellow; the environmental water quality warning integrated index of Tianjin in 2015 was 45.37/100 and the warning level was yellow; the environmental soil quality warning integrated index of Tianjin in 2015 was 36.34/100 and the warning level was orange; and the environmental water resources warning integrated index of Tianjin in 2015 was 66.14/100 and the warning level was green. The results showed that, in 2015, the warning integrated index of ecology, air quality, water quality, soil quality, and water resources of Tianjin were all lower and the soil quality warning integrated index was lower than other warnings. The reason for this was that, for a long time, due to the hidden and irreversible nature of soil pollution, Tianjin's attention to soil pollution was far lower than other pollutions. This phenomenon has changed since the State Council issued a notice of the action plan for the prevention and control of soil pollution in 2016. It was worth noting that the ecology warning integrated index was lowest. In fact, the lowest index could be attributed to the congenitally deficient natural endowments, the unfavorable hydrological conditions, the reduced regional ecological water volume, and the intensity of the regional development, which further endangered ecological security. In addition, although the water resources in Tianjin were very scarce, the environmental water resources warning integrated index was the highest in all the results. This was because, when using the integrated index method, some indicators were concealed by other indicators, for example, the water resources per capita was concealed by the water consumption per RMB 10,000 of GDP.

The evaluation results of the single index method and integrated index method all indicated that the ecological environment in Tianjin was facing more pressure and the air, water, soil and ecosystems were in a worse state. Although human beings had taken some measures to respond to the pressure and state in the region, their effect did not satisfy us.

\section{Discussion}

(1) Construction of index system: The research used the DPSIR model to construct the index system. Although it can reflect the relationship between human society and the environment, it was also a little unscientific and unreasonable. The linear causality in the DPSIR model oversimplified the actual situation and only represented the traditional "respond" concept of environmental protection. 
(2) Weight determination: The Analytic Hierarchy Process (AHP) method was used to determine the weights. Although it is practical and requires less quantitative data information, which is greatly convenient for our utilization, the Analytic Hierarchy Process (AHP) method has obvious deficiencies, which affected the evaluation results. First, the quantitative data are few and the qualitative components are numerous, so it is not convincing. Second, the large data statistics may make it difficult to determine the weights. In the next study, the Analytic Hierarchy Process (AHP) method should be combined with other methods to make the evaluation result more objective.

(3) The single and integrated index evaluation: To get more accurate results, this study used two methods to complement each other in the evaluation. The advantage of the single index method is that it can intuitively show early warning of a specific indicator. The advantage of the integrated index method is that it can analyze the overall situation of the region. However, the single index does not reflect the general trend of early warning in the region and the integrated index method sometimes is too one-sided to cover some of the serious indicators.

(4) A case study of Tianjin has proven that the index system and evaluation methods used in this article are appropriate and that it can be applied to other provinces and cities. In turn, the methods proposed in this paper also give us a deeper understanding of the environmental situation in Tianjin.

(5) Due to the lack of data, we made an empirical analysis of Tianjin in 2015. Compared to other studies, it may seem to lack a convincing basis. In view of this defect, first, we should add the data of Tianjin in other years or data of other cities in 2015; and second, we have to reduce the uncertainty in constructing the index system.

(6) Compared to other studies, this research put together carrying capacity, risk, and ecology warning, which can assess the environmental state in a certain place synthetically. It also combined the air, water, and soil elements to assess the full-scale warning.

\section{Conclusions}

The goal of this study was a methodological literature review of the environmental warning to improve the effectiveness and practicality of environmental warning in cities. This research was necessary to enhance the accuracy of environmental warnings. The following changes were made:

(1) The index system in this paper includes ecological protection, environmental quality (air, water, and soil) and water resources as three parts. All data are publicly available. We distinguished five classes, varying from the Driving forces (D) to the Responses (R), which can not only reflect the environmental state, but can also show the impact and responses of human beings.

(2) In this research, some new indicators were used, such as the population concentration degree and economic development level, which more accurately clarified the population and economy. In addition, two qualitative indicators (environmental management system soundness and environmental risk system perfection) made the index system more objective.

(3) The Analytic Hierarchy Process (AHP) method was chosen to determine the weights for the 28 indicators of the index system. The single index evaluation and the integrated index evaluation complemented each other to make the warning evaluation objective. Moreover, readers can understand the changes in the indicators and their good or bad trends by radar map.

(4) We applied this new method to Tianjin in 2015. The results were in accordance with the environmental conditions in that year. We could consider that we have achieved our purpose of creating new methods.

(5) Environmental management should be focused on to enhance the quality of the environment; for example, constructing ecological corridors and biodiversity conservation networks; implementing ecological protection and restoration projects of "mountain, water, forest, land, and lake"; strictly controlling project entry; establishing control lines of development and utilization to control the total amount of water; and speeding up enterprises to carry out 
water-saving transformation to effectively reduce industrial production of water consumption and sewage discharge.

(6) By a series of analyses, we could draw a conclusion: The method in this research made up for the shortcomings of the previous method. With the advantages of being concise and thorough, it combines the three aspects of the environment, ecology, and resources, especially in the water aspect which has three kinds of attributes. Besides these, it also considers air, water, and soil as the three environmental elements while most studies have not focused on soil. Overall, this paper put forward a successful method in environmental warning and environmental assessment that can be applied in cities and countries.

Author Contributions: W.W. analyzed data formally, proposed the research, conducted fieldwork, and drafted the original manuscript. Y.S. provided methodology. J.W. supervised the overall research project, acquired funding to support this research, and significantly contributed to the editing of the manuscript.

Acknowledgments: This research was supported by the National Natural Science Foundation of China (Grant numbers 41401658), and Strategic Environmental Assessment Research Center, Nankai University. We thank Azul Alysum, editor of MDPI, for editing the English text of a draft of this manuscript.

Conflicts of Interest: The authors declare no conflicts of interest.

Appendix

Table A1. The calculation method of each indicator.

\begin{tabular}{|c|c|}
\hline Indicator & Calculation Method \\
\hline Population concentration degree & $\begin{array}{c}\text { Population density }=\frac{\text { Total population }}{\text { Total land area }} \\
\text { Population concentration degree }=\text { Population density } \times \mathrm{d}\end{array}$ \\
\hline Economic development level & Economic development level $=$ Per capita GDP $\times \mathrm{k}$ \\
\hline \multicolumn{2}{|l|}{$\begin{array}{l}\text { Reduction of construction land area per } \\
\text { RMB } 10,000 \text { of GDP }\end{array}$} \\
\hline Industrial exhaust emissions per capita & Industrial exhaust emissions per capita $=\frac{\text { Industrial exhaust emissions }}{\text { Total population of the region }}$ \\
\hline Sewage discharge per unit area & $\begin{array}{c}\text { Sewage discharge per unit area }= \\
\frac{(\text { Domestic sewage discharge }+ \text { Industrial sewage discharge }+ \text { Other sewage discharge })}{\text { Total areas of the region }}\end{array}$ \\
\hline Fertilizer utilization rate & $\begin{array}{c}\text { Fertilizer utilization rate }= \\
\frac{\text { Nutrient components absorbed by plants }}{\text { Fertilizing amount }} \times 100 \%\end{array}$ \\
\hline Water consumption per RMB 10,000 of GDP & Water consumption per RMB 10,000 of GDP $=\frac{\text { Total water consumption }}{\text { Gross Domestic Product }}$ \\
\hline $\begin{array}{l}\text { Water consumption per RMB } 10,000 \text { of } \\
\text { industrial added value }\end{array}$ & $\begin{array}{l}\text { Water consumption per RMB } 10,000 \text { of industrial added value }= \\
\qquad \frac{\text { Total water consumption }}{\text { Industrial added value }}\end{array}$ \\
\hline Ecological redline rate & Ecological redline rate $=\frac{\text { Proportion of Ecological redline area }}{\text { The total land area }} \times 100 \%$ \\
\hline Cultivated land safety index & Cultivated land safety index $=\frac{\text { Actual area of cultivated land }}{\text { Redline area of cultivated land }}$ \\
\hline \multicolumn{2}{|l|}{ Eco-environmental quality index } \\
\hline $\begin{array}{l}\text { Percentage of days per year with good air } \\
\text { quality in cities }\end{array}$ & $\begin{array}{l}\text { Percentage of days per year with good air quality in cities }= \\
\frac{\text { Number of days per year with good air quality in cities }}{\text { Effective days of monitoring per year }} \times 100 \%\end{array}$ \\
\hline $\begin{array}{l}\text { Percentage of days per year with severe air } \\
\text { pollution in cities }\end{array}$ & $\begin{array}{l}\text { Percentage of days per year with severe air pollution in cities }= \\
\frac{\text { Number of days per year with severe air pollution in cities }}{\text { Effective days of monitoring per year }} \times 100 \%\end{array}$ \\
\hline $\begin{array}{l}\text { Centralized drinking water source quality } \\
\text { compliance rate }\end{array}$ & $\begin{array}{l}\text { Centralized drinking water sources quality compliance rate }= \\
\qquad \frac{\text { Water sources up to standard }}{\text { Total water source }} \times 100 \%\end{array}$ \\
\hline Water functional area compliance rate & 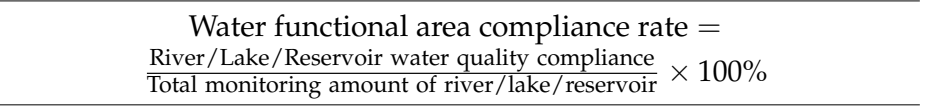 \\
\hline
\end{tabular}


Table A1. Cont.

\begin{tabular}{|c|c|}
\hline Indicator & Calculation Method \\
\hline Cultivated land soil quality compliance rate & $\begin{array}{l}\text { Cultivated land soil quality compliance rate }= \\
\frac{\text { Area of cultivated land up to standard }}{\text { Total area of cultivated land }} \times 100 \%\end{array}$ \\
\hline Contaminated land safe utilization rate & $\begin{array}{l}\text { Contaminated land safe utilization rate }= \\
\frac{\text { Area of safe utilization of contaminated land }}{\text { Total area of contaminated land }} \times 100 \%\end{array}$ \\
\hline Water resources per capita & Water resources per capita $=\frac{\text { Total amount of water resources in the region }}{\text { Total population in the region }}$ \\
\hline Water supply in ecological environment & Data is directly available \\
\hline Groundwater over-exploitation rate & 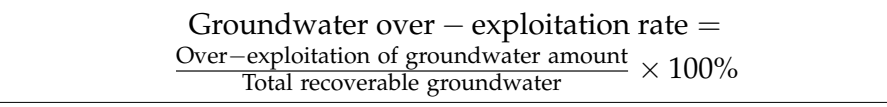 \\
\hline Forest coverage rate & Forest coverage rate $=\frac{\text { Forest cover area in the region }}{\text { Total area in the region }} \times 100 \%$ \\
\hline Soil erosion control rate & $\begin{array}{c}\text { Soil erosion control rate }= \\
\frac{\text { Total amount of soil erosion after government }}{\text { Total amount of soil erosion before government }} \times 100 \%\end{array}$ \\
\hline $\begin{array}{l}\text { Environmental management system } \\
\text { soundness }\end{array}$ & Qualitative indicator \\
\hline Environmental risk system perfection & Qualitative indicator \\
\hline Environmental pollution loss rate & $\begin{array}{c}\text { Environmental pollution loss rate }= \\
\frac{\text { Amount of environmental pollution loss in the region }}{\text { Total amount of GDP in the region }} \times 100 \%\end{array}$ \\
\hline $\begin{array}{l}\text { Effective utilization coefficient of farmland } \\
\text { irrigation water }\end{array}$ & $\begin{array}{l}\text { Effective utilization coefficient of farmland irrigation water }= \\
\qquad \frac{\text { Net water used by crops during the period of irrigation }}{\text { Total water intake from irrigation canal }}\end{array}$ \\
\hline Sewage centralized treatment rate & $\begin{array}{l}\text { Sewage centralized treatment rate }= \\
\frac{\text { Amount of sewage treated by sewage treatment plant }}{\text { Total amount of urban sewage discharge }} \times 100 \%\end{array}$ \\
\hline Recycled water utilization rate & 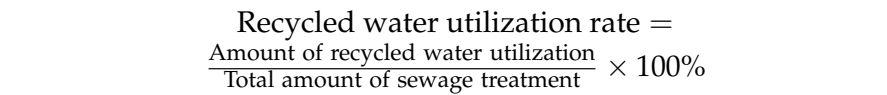 \\
\hline
\end{tabular}

Remark:

(1) d is the weight coefficient of the population growth rate, and the values of $\mathrm{d}$ are shown in Table A2.

Table A2. The values of $d$.

\begin{tabular}{cccccc}
\hline Population Growth Rate & $<0$ & $\mathbf{0 - 0 . 0 0 5}$ & $\mathbf{0 . 0 0 5 - 0 . 0 1}$ & $\mathbf{0 . 0 1 - 0 . 0 1 5}$ & $>\mathbf{0 . 0 1 5}$ \\
\hline Value of d & 0.8 & 1.2 & 1.4 & 1.6 & 1.8 \\
\hline
\end{tabular}

(2) $\mathrm{k}$ is the weight coefficient of Per capita GDP growth rate, and the values of $\mathrm{k}$ are shown in Table A3.

Table A3. The values of $k$.

\begin{tabular}{cccccc}
\hline Per Capita GDP Growth Rate & $\mathbf{< 5 \%}$ & $\mathbf{5 - 1 0} \%$ & $\mathbf{1 0 - 2 0} \%$ & $\mathbf{2 0 - 3 0 \%}$ & $>\mathbf{3 0} \%$ \\
\hline Value of k & 1 & 1.2 & 1.3 & 1.4 & 1.5 \\
\hline
\end{tabular}

\section{References}

1. United Nations Environment. Environment for the Future We Want; United Nations Environment Programme: Nairobi, Kenya, 2012.

2. Sun, L.Y.; Miao, C.L.; Yang, L. Ecological environmental early-warning model for strategic emerging industries in china based on logistic regression. Ecol. Indic. 2018, 84, 748-752. [CrossRef] 
3. Chen, G.J. Discussion on environmental early warning. Chongqing Environ. Sci. 1996, 18, 1-4. (In Chinese)

4. Wang, W.; Zeng, W. Optimizing the Regional Industrial Structure Based on the Environmental Carrying Capacity: An Inexact Fuzzy Multi-Objective Programming Model. Sustainability 2013, 5, 5391-5415. [CrossRef]

5. Glasgow, H.B.; Burkholder, J.A.M.; Reed, R.E.; Lewitus, A.J.; Kleinman, J.E. Real-time remote monitoring of water quality: A review of current applications, and advancements in sensor, telemetry, and computing technologies. J. Exp. Mar. Biol. Ecol. 2004, 300, 409-448. [CrossRef]

6. Parr, T.W.; Sier, A.R.J.; Battarbee, R.W.; Mackay, A.; Burgess, J. Detecting environmental change: Science and society-Perspectives on long-term research and monitoring in the 21st century. Sci. Total Environ. 2003, 310, 1-8. [CrossRef]

7. Diao, X.P.; Gao, J.; Wang, Y.; Yan, X.T. Environmental stress and impact evaluation of livestock and poultry excrement in Haikou. J. Agric. Resour. Environ. 2009, 26, 60-63. (In Chinese)

8. Xiong, J.X.; Chen, D.L.; Peng, B.F.; Wang, Y.L. Study on early warning of ecological carrying capacity in Dongting Lake Area based on ANN. J. Cent. South Univ. For. Technol. 2014, 34, 102-107. (In Chinese)

9. Lu, Y.L.; Liu, N.L.; Cheng, X.; Jiang, H.Q. Study on monitoring and prediction of regional atmospheric environmental carrying capacity in Beijing-Tianjin-Hebei Region. China Popul. Resour. Environ. 2017, S1, 36-40. (In Chinese)

10. Liao, E.; Jiang, Y.; Yan, X.H.; Chen, Z.; Wang, J.; Zhang, L. Allocation of marine environmental carrying capacity in the Xiamen Bay. Mar. Pollut. Bull. 2013, 75, 21-27. [CrossRef] [PubMed]

11. Wang, S.; Li, K.; Liang, S.; Zhang, P.; Lin, G.; Wang, X. An integrated method for the control factor identification of resources and environmental carrying capacity in coastal zones: A case study in Qingdao, China. Ocean Coast. Manag. 2017, 142, 90-97. [CrossRef]

12. Widodo, B.; Lupyanto, R.; Sulistiono, B.; Harjito, D.A.; Hamidin, J.; Hapsari, E.; Yasin, M.; Ellinda, C. Analysis of Environmental Carrying Capacity for the Development of Sustainable Settlement in Yogyakarta Urban Area. Procedia Environ. Sci. 2015, 28, 519-527. [CrossRef]

13. Yang, J.; Lei, K.; Khu, S.; Meng, W.; Qiao, F. Assessment of water environmental carrying capacity for sustainable development using a coupled system dynamics approach applied to the Tieling of the Liao River Basin, China. Environ. Earth Sci. 2015, 73, 5173-5183. [CrossRef]

14. Świąder, M.; Szewrański, S.; Kazak, J. Foodshed as an Example of Preliminary Research for Conducting Environmental Carrying Capacity Analysis. Sustainability 2018, 10, 882. [CrossRef]

15. Wang, Z.-G.; Luo, Y.-Z.; Zhang, M.-H.; Xia, J. Quantitative Evaluation of Sustainable Development and Eco-Environmental Carrying Capacity in Water-Deficient Regions: A Case Study in the Haihe River Basin, China. J. Integr. Agric. 2014, 13, 195-206. [CrossRef]

16. Jiang, H.Y.; Huang, Y.S. Study on Early Warning of Traffic Resources and Environment Carrying Capacity. J. Transp. Syst. Eng. Inf. Technol. 2015, 15, 10-16.

17. Cui, D.; Chen, X.; Zeng, W.-H. Investigations on the medium-to-long term early warning of water environmental carrying capacity-A case study of Kunming City. China Environ. Sci. 2018, 38, 1174-1184.

18. Zhu, J.W.; Xie, X.T.; Li, X.H. A solution to the problem of ecological environmental carrying capacity evaluation: A case study of Henan Province. Acta Ecol. Sin. 2017, 37, 7039-7047.

19. Zhou, D.J.; Wang, C.S. Specific evaluation of resource and environmental carrying capacity of urbanized areas for early-warning: A case study of the Beijing-Tianjin-Hebei region. Prog. Geogr. 2017, 36, 359-366.

20. Hou, L.M.; Yue, Q.; Wang, T. Research and Prospect of the Theoretical Framework of Water Environmental Carrying Capacity in China. Environ. Prot. Sci. 2015, 41, 104-108.

21. Pollert, J.; Dedus, B. Security of Water Supply Systems: From Source to Tap; Springer: Dordrecht, The Netherlands, 2006; Volume 8.

22. Pintér, G.G. The Danube accident emergency warning system. Water Sci. Technol. 1999, 40, 27-33. [CrossRef]

23. Wang, Y.; Zhang, W.; Engel, B.A.; Peng, H.; Theller, L.; Shi, Y.; Hu, S. A fast mobile early warning system for water quality emergency risk in ungauged river basins. Environ. Model. Softw. 2015, 73, 76-89. [CrossRef]

24. Wang, Y.; Engel, B.A.; Huang, P.; Peng, H.; Zhang, X.; Cheng, M.; Zhang, W. Accurately early warning to water quality pollutant risk by mobile model system with optimization technology. J. Environ. Manag. 2018, 208, 122-133. [CrossRef] [PubMed]

25. Liu, M.; Wei, J.; Wang, G.; Wang, F. Water resources stress assessment and risk early warning-A case of Hebei Province China. Ecol. Indic. 2017, 73, 358-368. [CrossRef] 
26. Li, Y.; Li, Y.; Kappas, M.; Pavao-Zuckerman, M. Identifying the key catastrophic variables of urban social-environmental resilience and early warning signal. Environ. Int. 2018, 113, 184-190. [CrossRef] [PubMed]

27. Djimesah, I.E.; Okine, A.N.D.; Kissi Mireku, K. Influential factors in creating warning systems towards flood disaster management in Ghana: An analysis of 2007 Northern flood. Int. J. Disaster Risk Reduct. 2018, 28, 318-326. [CrossRef]

28. Xu, Y.; Yang, W.; Wang, J. Air quality early-warning system for cities in China. Atmos. Environ. 2017, 148, 239-257. [CrossRef]

29. Wang, J.; Zhang, X.; Guo, Z.; Lu, H. Developing an early-warning system for air quality prediction and assessment of cities in China. Expert Syst. Appl. 2017, 84, 102-116. [CrossRef]

30. Zhao, H.; Wang, F.; Niu, C.; Wang, H.; Zhang, X. Red warning for air pollution in China: Exploring residents' perceptions of the first two red warnings in Beijing. Environ. Res. 2018, 161, 540-545. [CrossRef] [PubMed]

31. Cai, W.M.; Tang, H.J.; Chen, Y.Q.; Zhang, F.R. Land use system health evaluation framework and index selection. China Popul. Resour. Environ. 2004, 14, 31-35. (In Chinese)

32. Ma, S.W.; Xie, D.T.; Zhang, X.C.; Peng, Z.T.; Hong, H.K.; Luo, Z.; Xiao, J.J. Measures of land ecological security early warning and its spatial-temporal evolution in the ecologically sensitive area of the Three Gorges reservoir area: A case study of Wanzhou District, Chongqing City. Acta Ecol. Sin. 2017, 37, 8227-8240.

33. Chen, L.; Song, G.; Meadows, M.E.; Zou, C. Spatio-temporal evolution of the early-warning status of cultivated land and its driving factors: A case study of Heilongjiang Province, China. Land Use Policy 2018, 72, 280-292. [CrossRef]

34. Yang, X.L.; Liu, X.L. Effects of ecological security trend of pressure indexes on land eco-security-A case study in Zhuanglang County of Gansu Province. J. Gansu Agric. Univ. 2014, 1, 134-139.

35. Mei, B.L.; Chen, S.H. Inner Mongolia eco-environmental warning index system. Chin. Atmos. Sci. 2003, 26, 384-394. (In Chinese)

36. WU, K.N.; Guan, X.K.; Feng, X.W.; Lu, Q.L. The ecological environment quality warning of Zhengzhou using gray system based on the PSR Model. J. Henan Agric. Sci. 2007, 36, 83-85. (In Chinese)

37. Xu, X.G. Evaluation and early warning of the ecological environment in the Yellow River Delta. Acta Ecol. Sin. 1996, 16, 461-468. (In Chinese)

38. Zhu, W.H.; Miao, C.Y.; Zheng, X.J.; Wang, F.F. Study on ecological safety evaluation and warning of wetlands in Tumen River watershed based on $3 S$ technology. Acta Ecol. Sin. 2014, 34, 1379-1390. (In Chinese)

39. Chen, W.X.; Yang, X.R.; Li, Z.Q. The Analysis of Forest Landscape Patterns in East Dongting Lake Region Based on 3S Technology. Chin. Agric. Sci. Bull. 2015, 31, 1-9. (In Chinese)

40. Implementation Plan for the Reform of Environmental Impact Assessment in the 13th Five-Year Plan Period. Available online: http:/ /www.zhb.gov.cn/gkml/hbb/bwj/201607/t20160719_360949.htm (accessed on 28 April 2018).

41. United Nations Environment Programme (UNEP). Guidelines for Conducting Integrated Environmental Assessments; Global Environment Outlook; UN Environment: Nairobi, Kenya, 2017.

42. Bai, X.; Tang, J. Ecological security assessment of Tianjin by PSR model. Procedia Environ. Sci. 2010, 2, 881-887. [CrossRef]

43. National Environmental Protection Plan for the Thirteenth Five-Year. Available online: http://www.gov.cn/ zhengce/content/2016-12/05/content_5143290.htm (accessed on 21 April 2018).

44. Opinions on Implementing Strict Water Resources Management System. Available online: http:/ / www.gov. cn/zhuanti/2015-06/13/content_2878992.htm (accessed on 21 April 2018).

45. Opinions on the Delineation and Strict Adherence to the Control Line of Ecological Protection. Available online: http:/ / www.gov.cn/zhengce/2017-02/07/content_5166291.htm (accessed on 21 April 2018).

46. The Technical Guide for the Delimitation of the Control Line of Ecological Protection. Available online: http:/ /www.zhb.gov.cn/gkml/hbb/bwj/201505/t20150518_301834.htm (accessed on 21 April 2018).

47. Singh, R.P.; Nachtnebel, H.P. Analytical hierarchy process (AHP) application for reinforcement of hydropower strategy in Nepal. Renew. Sustain. Energy Rev. 2016, 55, 43-58. [CrossRef]

48. Wang, H.M.; Qiu, L. Resources-Environment-Economy Compound System Diagnostic Early Warning Method and Application; Science Press: Beijing, China, 2007; pp. 154-196, ISBN 9787030185655. (In Chinese) 
49. Ma, Y.; Gan, Q.; Huang, Q.; Yang, M. Practice and Exploration on Resources and Environmental Carrying Capacity Monitoring and Early Warning of Sichuan Province; Science Press: Beijing, China, 2017; pp. 357-390, ISBN 9787030521217. (In Chinese)

50. Guiding Opinions on the Implementation of Decreasing Construction Land Area per Gross Domestic Product in 13th Five-Year. Available online: http:/ / www.mlr.gov.cn/zwgk/zytz/201610/t201610091418810.htm (accessed on 21 April 2018).

51. Geng, Y.H.; Min, Q.W.; Cheng, S.K.; Chen, C.C. Temporal and spatial distribution of croplandpopulation-grain system and pressure index on cropland in Jinghe watershed. Trans. Chin. Soc. Agric. Eng. 2008, 24, 68-73. (In Chinese)

52. Shao, C.F.; Ju, M.T.; Zhang, Y.F.; Li, Z. Eco-environment security assessment study for the Binhai New Area, Tianjin, based on DPSIR model. J. Saf. Environ. 2008, 8, 87-92. (In Chinese)

53. Ministry of Housing and Urban Rural Development. Soil Erosion Prevention and Control Standards for Construction Projects; (GB50434-2008); Ministry of Housing and Urban Rural Development: Beijing, China, 2008.

54. Indicators of National Ecological Civilization Demonstration Counties and Cities (Trial Implementation). Available online: http://www.zhb.gov.cn/gkml/hbb/bwj/201601/t20160128_327045.htm (accessed on 21 April 2018).

55. Action Plan for Zero Growth of Fertilizer Consumption by 2020. Available online: http:/ /jiuban.moa.gov. cn/zwllm/tzgg/tz/201503/t20150318_4444765.htm (accessed on 21 April 2018).

56. Action Plan for the Prevention and Control of Soil Pollution. Available online: http:/ / www.gov.cn/zhengce/ content/2016-05/31/content_5078377.htm (accessed on 21 April 2018).

57. Yang, Z.F.; Yin, M.; Cui, B.S. Study on urban eco-environmental water requirements: Theory and method. Acta Ecol. Sin. 2005, 25, 389-396. (In Chinese)

58. Ministry of Water Resources. Guidelines for the Evaluation of Groundwater Overdraft Area; (GBT 34968-2017); Ministry of Water Resources: Beijing, China, 2017.

59. Green Is Gold: The Strategy and Actions of China's Ecological Civilization. Available online: http:/ / web.unep.org/greeneconomy/sites/unep.org.greeneconomy/files/publications /greenisgold_en_ 20160519.pdf (accessed on 24 April 2018).

60. Xu, Y.Y.; Qian, M.L.; Li, X.; Wang, X.R.; Xie, Y.J. Assessment of Ecological Security for Taiping Lake Watershed Based on the DPSIR Model. J. Fudan Univ. 2015, 54, 407-415. (In Chinese)

61. Tianjin Statistical Yearbook in 2015. Available online: http:/ / stats.tj.gov.cn/Item/25858.aspx (accessed on 26 April 2018).

62. Tianjin Environmental Statement in 2015. Available online: http:/ / www.tjhb.gov.cn/root16/mechanism/ standard_monitoring_of_the_Department_of_science_and_technology/201609/t20160913_23279.html (accessed on 26 April 2018).

63. Tianjin Water Development Statistical Bulletin in 2015. Available online: http://www.tjsw.gov.cn/pub/ tjwcb/zhengcefg/zcfg/zcfg_gztb/201609/t20160905_48145.html (accessed on 26 April 2018).

64. Tianjin Water Resources Bulletin in 2015. Available online: http:/ /www.tjsw.gov.cn/pub/tjwcb/zhengcefg/ zcfg/zcfg_gztb/201611/P020161111366223645595.pdf (accessed on 26 April 2018).

(C) 2018 by the authors. Licensee MDPI, Basel, Switzerland. This article is an open access article distributed under the terms and conditions of the Creative Commons Attribution (CC BY) license (http:/ / creativecommons.org/licenses/by/4.0/). 